\title{
Code Mixing in Song Lyrics as a Form of Regional Language Defense (?)
}

\author{
Muhardis $^{1}$, Putri Dian Afrinda ${ }^{2}$ \\ \{adi_perdana2000@yahoo.com ${ }^{1}$, putridian_afrinda@yahoo.com ${ }^{2}$ \} \\ Pusmenjar, Balitbangbuk, Kemdikbudristek ${ }^{1}$, Universitas Perintis Indonesia ${ }^{2}$
}

\begin{abstract}
Mixing language codes in a song's lyrics has become commonplace. Generally, the mixed code comes from foreign language fragments. Concerning this, there is a phenomenon that occurs in Minangkabau, West Sumatra. They mix language codes, not only foreign languages but also Minangkabau language codes into Indonesian song lyrics. Uniquely, Minangkabau language code mixed not only in the form of original vocabulary but also in the form of interference. The goal is to emphasize the humorous or humorous elements in the song. In addition, they hope that the fragments of the Minangkabau language can be remembered by teenagers who began to be embarrassed using the language of the region. There are form of mixed code: tak nia 'dislike', penduta 'lier', padiarin 'leave it', and berkada 'scabies'. Song lovers will find it funny and easy to remember the flakes that are indirectly the language of the 'slip of the tongue'area.
\end{abstract}

Keywords: Mix Code; Interference; Song Lyrics; Regional Language Defense; Minangkabau Language

\section{Introduction}

This article is a continuation of the previous article entitled Code Mixing In The Up To Date Dangdut Song Lyrics presented in The First International Communication Through Language Literature and Art in 2017. In the writing, the form of mixed code is found in the form of scolding with the type of circumstance. The cause of the code mix is the desire to explain and interpret, give mentions, swearing, or certain forms of language that correspond to the circumstances experienced. Due to the absence of the right form of language to use, finally selected alay form such as Kepo namely from English knowing everything particular object, which in Indonesian means the nature of wanting to know all the affairs of others. Other examples, Kamseupay, acronym of KAMpungan, SEkali Udik PAYah.

Interestingly, four years after the phenomenon, it seems that code-mixing is still used in some song lyrics, especially songs popularized by Minangkabau millennials in Padang City. The difference is, the mix of code in the lyrics of the song is currently signaled to be used as a form of effort to defend the regional language. The mixed form of code used is not only a specific language code but also in the form of interference. Interference that is corrected with a certain pattern is mixed into the lyrics of songs written in Indonesian. When the lyrics of the song are sung, the ethnicity outside Minangkabau will not be able to capture its meaning. 
Unlike those who have Minangkabau. They can easily interpret it, it can even make them laugh because the form of language is considered funny.

The lyricist deliberately mixed Minangkabau language code into the Indonesian language code in the song lyrics intending to add antics to the lyrics of the song so that the song is easily accepted in the hearts of the listener. Refers to the theory of joking relationship [1], mix the code deliberately presented by the lyricist in the hope that the audience is at one "frequency", namely having the proximity of regional language, humor can occur. Similarly, perceptions formed due to cultural differences [2], listeners who are outside the "situation" will be astonished, as a feature of configuration theory [3], due to the illogical use of language elements and led them to search for the meaning of "codes" deliberately mixed with lyricists. Indirectly, they will study the language code of the area, look for a form of language that has a close meaning, and then can interpret the lyrics thoroughly. This effort can be assessed as a form of regional language defense through the medium of song lyrics.

Concerning configuration theory, Acehnese humor is known as misunderstanding theory [4], humor formed by misunderstandings stems from the misinterpretation of the meaning of the word. In the case of Indonesian song lyrics mixed with fragments of the Minangkabau language, some fragments can be interpreted directly (because it is a Minangkabau language code), but some can not be found meaning in the Indonesian dictionary or Minangkabau language dictionary. The fragment can be interpreted if the listener can scan words that morphologically have similar forms in the Minangkabau language. The debris is suspected to be from the Minangkabau language which is experiencing interference, both morphologically and syntactically [5], known from the singer who is well known as a speaker Minangkabau language. Based on the form of humor, the mix of code in the lyrics of this song belongs to the form of humor in rhys, in British culture known as limericks [6], but it has a difference in the number of rows and the number of courses. The average lyric is written in four to five lines for each section. For the content, mixed code used is a type of social humor, which involves people of different ages and topics.

Traces to the theory of language in humor, namely script-based semantic theory [7], deviations against semantic can damage balance and cause humor. This deviation is used by the lyricist of the song to make the song witty. Situationally, antics or cuteness can also be formed from the absence of parallels between what is expected, assumed, and reality. The use of humor, according to Whorf, cannot be separated from the understanding of the culture of the owner's community [8]. During this time, the planting of mixed code concepts revolves around the use of two or more languages in a multilingual speech society. The cause is also emphasized on the ability of the speaker in using a certain language [5]. In addition, the presence of other speakers, the variety of speech, situation, time, and purpose of speech [9] are some of the causes of code-mixing. In this case, the mix of code is done consciously to create a witty or funny impression as well as efforts to defend the language of the region that began to be abandoned by the speaker because it is considered kampungan [10] or loss of interest in regional languages [11].

Mixed code can be seen as an effort to defend the language of the region refers to the opinion that language defense can be done by generating a positive language attitude for the spoken community, a proud attitude towards the language itself [12]. The concept of language defense has more to do with the prestige of a language in the eyes of its supporting community. Language defense is related to changes in the stability of language use on the one hand with psychological, social, and cultural processes on the other hand in multilingual societies [13]. In the context of pride in yourself, mixing fragments of Minangkabau language (although in some lyrics in the form of interference) can be judged as a positive language 
attitude. However, it is good if the form of interference is minimized in its use. However, a proud attitude towards the language itself should be supported by a good attitude of using language. This refers to the adagium of the Indonesian language, preserve the regional language, and master the foreign language.The preservation of the language of the region contains the meaning of protection from extinction or destruction. That is, love for the language of the region must be accompanied by protection efforts.

The results of this study in the future can enrich sociolinguistic research, especially mixing code and interference. For learning in universities, especially linguistic interests, if during this time the study of sociolinguistic courses emphasizes the understanding of mixed concepts of code and interference, through the results of this study, students can be trained to develop student literacy skills. They not only understand the concept but can also explore the whys of the people of an area using mixed codes in daily life. The lyrics of the song that was used as the source of this research data are Indonesian song lyrics sung by the original Minangkabau singer. Data is limited to some song lyrics that are signaled to use mixed code to create a witty impression. The results showed that the mix of codes found in Indonesian song lyrics is to mix code with foreign languages, mix code with Minangkabau language, and mix code with interference fragments.

\section{Literature Review}

Research on mixing code in song lyrics is nothing new in the field of language. Generally, these studies describe what kind of language is mixed. Foreign languages rank first in languages that are often used as fragments of mixed code. Foreign languages are like English and Arabic [14], [15], [16]. Even in Japanese song lyrics, English flakes also dominate. The difference is that English splinter mixing is done for phrases that cannot be defined in Japanese [17]. In addition to the non-definitional phrases, English flakes are also used to evoke a sense of humor in the lyrics of Chinese songs [18].

In addition to foreign languages, regional language fragments are also used as a mix of code in song lyrics. Indonesian song lyrics mixed with Javanese flakes are done to cause antics of the song even in the form of expressions of resentment [19]. Meanwhile, research conducted on mixing code in Acehnese song lyrics found that Acehnese language fragments were used to represent the mandate to be delivered [20]. A speaker, for example, who in Indonesian slips a lot of fragments of his local language, can be said to have mixed the code [5]. Elements of some languages are inserted in other languages, so they have interrupted their function and support the function of the language they are sidelined in. This is a hallmark of the symptoms of mixed code [13].

Causes of code-mixing [13] there are two things: mix the code that is outward and inward. Mixing code occurs when inserting regional language elements into the national language, elements of the dialect into its regional language, or elements of its variety and style into its dialect. In addition, code-mixing occurs due to the reciprocal relationship of the role of the speaker, the form of language, and the function of the language. This means that speakers with a certain social background tend to choose a specific form of code mix to support certain functions. It is intended to show his social status and personal identity in society. 


\section{Method}

The method used in this study is a qualitative descriptive method [21] i.e. based solely on existing facts or phenomena that are empirically alive to the speakers. Data collection using simak 'listen carefully' method with basic techniques of tapping techniques and advanced techniques of simak libat cakap 'listen carefully \& engages in conversation' and catat 'record' techniques. The source of this research data is all Songs in Indonesian, humorous songs, assumed to contain mixed events code, and sung by the Minang original artist. Data analysis is done using padan translasional 'commensurately translational' method.

\section{Results and Discussion}

After the investigation, it was found that some songs that are assumed to contain mixed events code. The lyrics of the song found some form of mixed code. Here's the description.

\subsection{Mixed form of Minangkabau Language Code}

Inner code-mixing [22] found in the form of Minangkabau words, phrases, and sentences.

Ribuik urang semua

Dedek lameh jadinya

Nanti dedek kuih

Mengaku maco

Tik gitik gitik gali dong sayang

Cik picik picik sakik dong sayang

“Upiak Isil-Malas Dedek Mah”

"Lepai jo Bundo-Gitik-Gitik"

In the lyrics of the song above, there are forms of mixed code inwards. In the lyrics found minangkabau language word, namely ribuik/ribut/ 'noisy', lameh /lemas/ 'very weak', kuih /kurus/ 'thin', maco /macho/ 'manly', gali /geli/ 'amused', dan sakik/sakit/ 'sick'.

There is also a word that is the name of the day.

Hari Sanayan hari liburku

Hari Rabaa juga liburku

Hari Jumaik juga liburku

“Lepai-Kegiatan Harian”

In the lyrics mixed Minangkabau language code for identity name of the day, that is Sanayan /Senin/ /Monday/, Rabaa /Rabu/ 'Wednesday', dan Jumaik/Jumat/ 'Friday'.

Mengaku maco, angok baun nago.

$$
\text { "Upiak Isil-Malas Dedek Mah" }
$$

In the lyrics of the song above, there are Lyrics mengaku maco, angok baun nago consists of two sentences, namely (1) Mengaku maco 'Manly' and (2) Angok baun nago 'bad breath like dragon'. Sentence (1) is an Indonesian sentence patterned Subject-Verb-Object (SVO) 
with element S disappeared. Sentence (2) is a patterned Minangkabau language sentence SV, that is angok /napas/ 'breath' fill element $\mathrm{S}$ and baun nago /bau seperti bau napas naga/ 'bad breath like dragon' fill element $\mathrm{V}$.

\subsection{Mixed form of code with Foreign Language}

Ku bilang wo ai ni engkau sumpah mati Kubilang i love you janjian ketemu

“Ajo Buset-Cinta 123"

The lyrics shown an outer code-switching event in the form of a clause. Mixed events of code sourced from foreign languages i.e. Mandarin in the form of Wo Ai Ni and English in the form of I Love You. The mixing of Indonesian with Mandarin and English aims to convince someone of their seriousness when expressing feelings. A mixed foreign language is a language that is already known or commonly meaning by the interlocutor or someone addressed by the singer. The foreign language used in song lyrics is usually a foreign language that is already popular and known by the listener. It is also intended so that the songs sung can be easily known and understood by the public. Other forms of foreign languages can be seen in the following data.

$$
\begin{aligned}
& \text { Is the best lah buatmu } \\
& \text { Always to love taroroh } \\
& \text { Dewi... i can't stop } \\
& \text { Dewi.. . no smoking }
\end{aligned}
$$

$$
\text { “Ajo Buset-For Mantan" }
$$

“Ajo Buset-Dewi"

Similar to the previous lyrics, the foreign language (English) used is a foreign language that diction does not require a special sense. The use of foreign language diction in the lyrics of this song in principle aims to foster the impression of suspense for the appeal of the listener community.

\subsection{Form of Interference}

The next mixed form of code found is interference code. After conducting translational equivalent analysis by matching the language form with the Minangkabau language and Indonesian language it was found that a form is a form of Minangkabau language interference to The Indonesian language.
Abang penduta.. malas dedek mah... Padiarinlah saja Antap-antap saja dedek tak nia

In these lyrics, there are several forms of interference. Lyrics with interference are found in the word penduta, padiarinlah, antap-antap, and nia. The word penduta similar form and 
meaning to minangkabau language words panduto /pendusta/ 'lier'. The word panduto changes the phoneme /o/ to /a/ at the end of the word. In addition, the affix pa-N becomes pe$\mathrm{N}$ following the Indonesian fixation. This change also applies to the interference of the word nio 'want' to be nia.

Furthermore, the word padiarinlah has similarities with the word padia 'leave it' in Minangkabau language. The rin form that follows the word padia refers to the non-standard form of /biar/ 'leave it'. Next word, antap-antap has a closeness of form to the word antokantok/diam-diam/ 'secretly'. Phoneme /k/ on syllable -ok the word antok turns into phoneme /p/. This may mimic the usual form of the word atok /atap/ 'roof', langkok /lengkap/ 'complete', kudok/kudap/ 'taste'.

In addition to the change of phoneme $/ \mathrm{k} /$ to $/ \mathrm{p} /$ at the final position of the syllabus -ok, the phoneme $/ \mathrm{k} /$ will also change to the phoneme $/ \mathrm{t} / \mathrm{when}$ it is at the final position of the syllabus -ek. An example can be seen in the following data.

Kita minum fanta ciat berdua

“Ajo Buset-Cinta 123"

The word ciat in the lyrics is close to the form and meaning with the Minangkabau language ciek word meaning 'one'. The phoneme $/ \mathrm{k} /$ turns into a phoneme $/ \mathrm{t} /$ following a commonly used pattern, namely silek/silat/, bulek/bulat/ 'circle', dan kuek/kuat/ 'strong'.

Phoneme changes also occur for the $/ \mathrm{v} /$ phoneme at the initial position of the word. An example can be read in the following lyrics.

walau agak perboden gai

$$
\text { “Ajo Buset - Dewi" }
$$

The word perboden similar in shape and meaning to the Indonesian word verboden. This indicates the change of phoneme/v/ to phoneme /p/ because Minangkabau ethnicity does not recognize the sound $[\mathrm{v}]$ in their language. In the past, all frikative consonant sounds such as /f/ and $/ \mathrm{v} /$ would be pronounced as /p/, following the habit of pronunciation pebruari /Februari/ 'February', pentilasi /ventilasi/ 'ventilation', pernis /vernis/ 'varnish'. This habit occurs due to the process of receiving foreign language elements conducted in audio fashion [23] which over time was grateful as a vocabulary. With the development of the times, they have been able to recite as they should, especially those who have received a decent education. Interestingly, the words are deliberately raised to affirm the antics of the song.

In addition to phoneme changes, the form of interference mixed into the song's lyrics is the addition of phonemes.

Walapun cuman mantanku

$$
\text { “Ajo Buset-For Mantan" }
$$

The word cuman has a similar shape to the word cuma 'only' in Indonesian. There is an addition of the phoneme $/ \mathrm{n} /$ to the final position of the word. No one can predict the cause of adding phonemes at the end of a word. Another word that gets added at the end of the word is the word /ibu/ 'Mrs' becomes /ibuk/, /nanti/ 'later' becomes nantik. Phoneme additions occur in words that end in vocal phonemes although not in all words. The forms of interference contained in the lyrics of the song is a form of influence of regional language mastery (Minangkabau) on the Indonesian language. 


\subsection{Form of Healing Interference}

In addition to interference in the form of basic words, the form of healing interference is also used as a mix of code in the lyrics of the song.

Dedek sudah tersurut

Jangan meribuik juga

Abang berkada.

“Upiak-Malas Dedek Mah”

The three lyrics contain three forms of healing words, namely tersurut, meribuik, and berkada. These words have the prefix form ter-, me-, and ber- as active verbs. Minangkabau language recognizes the three affixes as affixes $t a-, m a-$, and $b a-$. These prefixes are attached to the base word /surut/ 'recede', ribuik/ribut/ 'noisy', dan kada/kadas,kudis/ 'scabies'.

If you follow the Minangkabau language rules, the three healing forms can be written as: ta-suruik, ma-ribuik, and ba-kada. In this case, all three prefixes of Minang language are changed to Indonesian prefixes. The change is certainly ungrateful. Otherwise with the word tersurut. The word tersurut grateful in Indonesian in the sense of 'tawar hatinya' 'tasteless'.

\subsection{Mixed form of the Particles Code ku-mu-nya}

The particles of $k u$ 'my', mu 'his/her', nya 'their', in Indonesian are also found as a form of mixed code in the lyrics of the song. The particle is attached to the Minang root word.

Ketika dikau di rumah bakoku

Kukijok dirimu

"Ajo Buset - Cinta 123"

asoynya sudah tabang

tiok malam kubatanggang

“Ajo Buset-Asoy Tabang”

akan kutampuah je nyeh

“Ajo Buset-Dewi"

The particle of $k u$ attached to the basic Minangkabau language in the lyrics is bako /saudara ayah/ 'father's brother', 'kijok/kedip/ 'wink', asoy/kantong dari plastik/ 'plastic bag', batanggang /begadang/ 'stay up late', dan tampuah /tempuh/ 'travel'. The resulting form becomes meaningless semantically because it can not be interpreted in Indonesian or the Minangkabau language.

\subsection{Mixed form of Question Word Code}

Based on some song lyrics analyzed only found one form of mixed code that uses the word question. The question word found is the question word apo /apa/ 'what' attached to particles lah as a marker of emphasis.

apolah salah aku ini 
“Ajo Buset-Asoy Tabang"

\subsection{Mixed form of affirmation word code}

The affirmation word used as a form of code mix is the word je nyeh Minangkabau language which is a short form of sajo nyoh 'only you'which in Pariaman dialect becomes je nyeh.

hanya dirimu, dirimu je nyeh

“Ajo Buset-Dewi”

\section{Conclusion}

Based on the results of the analysis and discussion that has been described against the lyrics of Indonesian songs by Minang singer above, it can be concluded that some forms of mixed code used, namely, mixed forms of Minangkabau language code, foreign languages, forms of interference, affixation interference, mixed code parties, words asked, and affirmation words were found. This mixed form of code aims to create humor or humor.

\section{References}

[1] A. Mahadev L, M. Lawrence E., D. L. F. Nilsen, and A. P. Nilsen, "Humor and Laughter: An Anthropological Approach," J. Am. Folk., vol. 99(393):33, 1986, doi: DOI:10.2307/540824.

[2] J. Tonglin, "Cultural Differences in Humor Perception, Usage, and Implications," Front. Psychol., 2019, doi: 10:123. DOI:10.3389/fpsyg.2019.00123.

[3] G. Jeffrey H. and M. Paul E, The Psychology of Humor. New York: Academic Press, 1972.

[4] Y. Bakhrum, Jenis dan Fungsi Humor dalam Masyarakat Aceh. Jakarta: Pusat Pembinaan dan Pengembangan Bahasa, 1997.

[5] A. Chaer, Sosiolinguistik Perkenalan Awal. Jakarta: Rineka Cipta, 2010.

[6] S. Christoph, S. Mohr, and M. H. Fischer, "Listening to Limericks: A Pupillometry Investigation of Perceivers," PLoS One, vol. 8, no. (9):e74986, 2013.

[7] R. V, "Semantic Theory of Humor," Semant. Mech. Humor, pp. 99-147, 1985, doi: 10.1007/978-94-009-6472-3_4.

[8] W. I Dewa Putu and M. Rohmadi, Sosiolinguistik: Kajian Teori dan Analisis. Yogyakarta: Pustaka Pelajar, 2013.

[9] J. A. Fishman, "The Relationship between Micro and Macro Sociolinguistics in The Study Who Speaks What Language to Whom and When," in Pride and Holmes, 1976, pp. 15-32.

[10] P. Icuk, "Bisakah Bahasa Daerah Bertahan?," in Prosiding Seminar Kebijakan Bahasa Pascaorba: Sebuah Penguatan Identitas, 2015.

[11] P. I Nyoman Adi Jaya, "Upaya Strategis Pemertahanan Bahasa Daerah Milenial," Bali, Jun. 29, 2020.

[12] D. I Putu Mas, "Sikap Bahasa, Pilihan Bahasa, dan Perilaku Sosial," Denpasar, Jun. 19, 2020.

[13] R. Fathur, Sosiolinguistik: Suatu Pendekatan Pembelajaran Bahasa dalam Masyarakat 
Multikultural. Yogyakarta: Graha Ilmu, 2011.

[14] R. Iza, "Campur Kode yang Digunakan dalam Lirik Lagu Berbahasa Minangkabau oleh Penyanyi Upiak Isil,” Universitas Andalas, 2019.

[15] Trisfayani, "Analisis Campur Kode dalam Lirik Lagu Aceh Album "Boh Hate 2 Goyang Lagi," Visipena, vol. 8, no. 1, 2017, doi: https://doi.org/10.46244/visipena.v8i1.384.

[16] R. Igas Amalia, "Campur Kode dalam Liriklirik Lagu Karya Project Pop,” Universitas Jember, 2013.

[17] S. Esa Ufi, “Alih Kode dan Campur Kode dalam Lirik Lagu Band Vamps,” Universitas Diponegoro, 2017.

[18] S. Ilham and M. Mintowati, "Alih Kode dan Campur Kode pada Llirik Lagu dalam Album 一心向前 (YIXIN XIANG QIAN),” Mandarin Unesa, vol. 1, no. 3, 2018.

[19] A. Devi and R. Setyorini, "No Title," J. SAP, vol. 2, no. 3, 2018.

[20] Nurmina and N. Aflah, "Campur Kode dalam Lirik Lagu 'Bergek,"” J. Pendidik. Almuslim, vol. 3, 2017.

[21] Sudaryanto, Metode Dan Aneka Teknik Analisis Bahasa. Yogyakarta: Duta Wacana University Press, 1993.

[22] J. Wayan, Dasar-Dasar Sosiolinguistik. Denpasar: Ikayana, 1991.

[23] A. Anni and I. Winingsih, "Campur Kode pada Album Don’t Stop oleh Ai Carina Uemura," Lite, vol. 11, no. 2, 2015. 